\title{
Living as Befits a Knight: New Castles in Seventeenth-Century Holland
}

\author{
Konrad Ottenheym
}

\section{1 \\ Introduction: Seventeenth-Century 'Gothic’ Architecture}

From the 1630 s onwards, the ideal of building according to principles of 'true' architecture as formulated in Antiquity by Vitruvius and more recently by Italian architects like Palladio and Scamozzi, had become decisive in the further development of Dutch architecture. ${ }^{1}$ The Mauritshuis in The Hague (1633-1644) was one of the first convincing specimens of this new building style. Thanks to Huygens' mediation, Jacob van Campen became involved not long afterwards in one of the Prince of Orange's key construction projects: in 1639, he designed the new front façade of, and oversaw an extensive renovation of, the Oude Hof at Noordeinde in The Hague, now known as Noordeinde Palace. From that moment on, Italianate Classicism came to be regarded as the Republic's courtly style and went on to be imitated widely in the country, both among the nobility and by the civic authorities and leading bourgeoisie. Town halls, grand houses along the cities' canals, churches and orphanages - almost all new public and private construction projects were designed in the new style from about 1640 onwards. Even in the instances where the result was not a runaway success, the Classical idiom was at least applied as façade ornamentation. It seemed that there was no interest in Gothic architectural forms in this climate. Where they were discussed in texts, they tended to be dismissed as the epitome of an antiquated building style, and some writers, aping a handful of influential Italian theorists of art, even called these forms 'barbaric' on

1 This contribution is also published in Dutch, as chapter 9 in Enenkel K.A.E. - Ottenheym K.A., Oudheid als ambitie. De zoektocht naar een passend verleden (Nijmegen: 2017). See for the influence of Scamozzi on Dutch classicist architecture (with further bibliography) among others: Ottenheym K.A., Schoonheid op Maat. Vincenzo Scamozzi en de architectuur van de Gouden Eeuw (Amsterdam: 2010). Ottenheym K.A., "The best and most competent at observing proportion'. Scamozzi's posthumous success in 17th-century Holland", in Barbieri F. Avagnina M.E.- Sanvito P. (eds.), Vincenzo Scamozzi. Teorico Europeo (Vicenza: 2016) 194-231.

(C) KONRAD OTTENHEYM, 2019 | DOI:10.1163/9789004378216_014

This is an open access chapter distributed under the terms of the prevailing CC-BY-NC-ND License 
occasion. ${ }^{2}$ Nevertheless, there were some rare situations where the clean-lined classical idiom of the day was deliberately passed over in favour of the "oldfashioned" idiom of Gothicism. In fact, this was the case across Europe.

Most cases where Gothic applications were chosen were in the completion or extension of mediaeval churches, where preserving the unity of architectural style trumped the consideration of making a single component of the building a showcase of contemporary building. ${ }^{3}$ Examples of this from the Province of Holland include the "Gothic" designs of Jacob van Campen, circa ${ }_{1645}$, for the (never-completed) tower of the Nieuwe Kerk on the Dam in Amsterdam, and the new vestry (1658) of St. Bavo's church in Haarlem by Salomon de Bray [Fig. 12.1]. ${ }^{4}$ Even new churches built in a more up-to-date idiom often sported emphatically recognisable long, narrow windows with tracery redolent of the traditional church windows of the Middle Ages. In recognition of their origins, German sources of the age literally call them Kirchenfenster (church windows) or describe them as 'windows in ecclesiastical style' (kirchischer Stil). ${ }^{5}$ In many seventeenth-century Protestant churches in the Netherlands, too, elongated windows with modern tracery were installed, such as in Hendrick de Keyser's churches in Amsterdam [Fig. 12.2], the Marekerk in Leiden, and the Nieuwe Kerk in The Hague. ${ }^{6}$ Evidently, this was a way of denoting a building, be it

2 Jongh E. de, "t Gotsche krulligh mall'. De houding tegenover de gotiek in het zeventiendeeeuwse Holland", Nederlands Kunsthistorisch Jaarboek (1973) 85-145.

3 Celebrated examples are the sixteenth-century designs for the façade of San Petronio in Bologna; the mid-seventeenth-century new Marian chapel beside the choir of the Gothic cathedral of St. Goedele in Brussels; and Nicholas Hawsmoor's towers for Westminster Abbey, dating from the early eighteenth century. Wittkower R., Gothic vs Classic: Architectural Projects in Seventeenth-Century Italy (New York: 1974). Hall M. (ed.), Gothic Architecture and its Meanings 1550-1830 (Reading: 2002). Rousteau-Chambon H., Le gothique des Temps modernes. Architecture religieuse en milieu urbain (Paris: 2003).

4 Dunk Th. von der, "Hoe klassiek is de gothiek? Jacob van Campen en de toren van de Nieuwe kerk te Amsterdam. Een nieuwe benadering van een oude kwestie", Jaarboek Amstelodamum 58 (1993) 49-9o; idem, Toren versus traditie. De worsteling van classicistische architecten met een middeleeuws fenomeen (Leiden: 2015); Tussenbroek G. van, De toren van de Gouden Eeuw. Een Hollandse strijd tussen Gulden en God (Amsterdam: 2017).

5 Sutthoff L.J., Gotik im Barock. Zur Frage der Kontinuität des Stiles ausserhalb seiner Epoche. Möglichkeiten bei der Stilwahl (Münster: 1990), and Hipp H., "Die 'Nachgotik' in Deutschland, kein Stil und ohne Stil", in Hoppe S. - Müller M. - Nussbaum N. (eds.), Stil als Bedeutung in der nordalpinen Renaissance. Wiederentdeckung einer methodischen Nachbarschaft (Regensburg: 2008) $15-46$.

6 Ottenheym K.A., "The attractive flavour of the past. Combining new concepts for ecclesiastical buildings with references to tradition in seventeenth-century Holland", in Harasimowicz J. (ed.), Protestantischer Kirchenbau der Frühen Neuzeit in Europa. Grundlagen und neue Forschungskonzepte / Protestant Church Architecture in Early Modern Europe. Fundamentals and new research approaches (Regensburg: 2015) 99-114. 


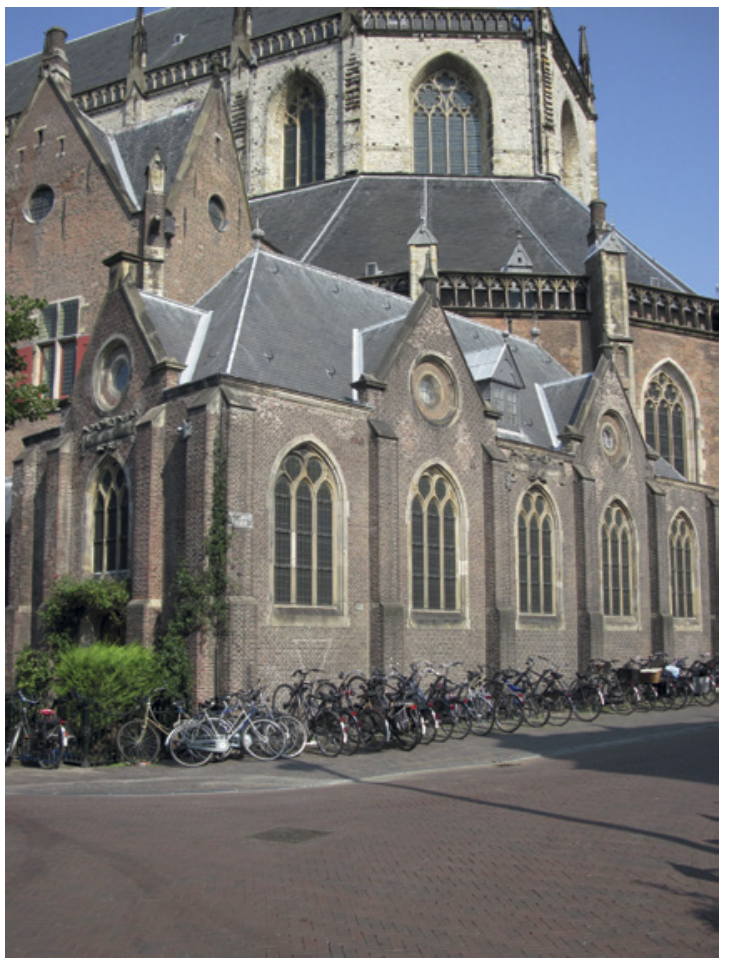

FIGURE 12.1

Salomon de Bray (architect), The new vestry behind the choir of St. Bavo's church in Haarlem (1658)

IMAGE (C) AUTHOR

never so new and daring, as an instantly-recognisable Christian place of worship. This type of recapitulation of Gothic architectural forms is not a reference to any given period of the past, for that Catholic past had now very much been left behind. Rather, the use of these 'church windows' was meant to stamp a building as a Christian church. As such, this group of buildings falls outside the scope of the present volume and will not be considered any further.

Another significant group of buildings which consciously continued to use architectural elements from the Middle Ages were the castles and the nobility's rural stately homes. Here, allusions to the past very much did have a crucial role.

All over Europe, castles had for centuries been the nobility's bases. In the Middle Ages, the structure's defensive nature was inextricably linked to its other functions as the residence for the local nobleman and as a military supply point for his authority. Continuing into the Early Modern period, military 


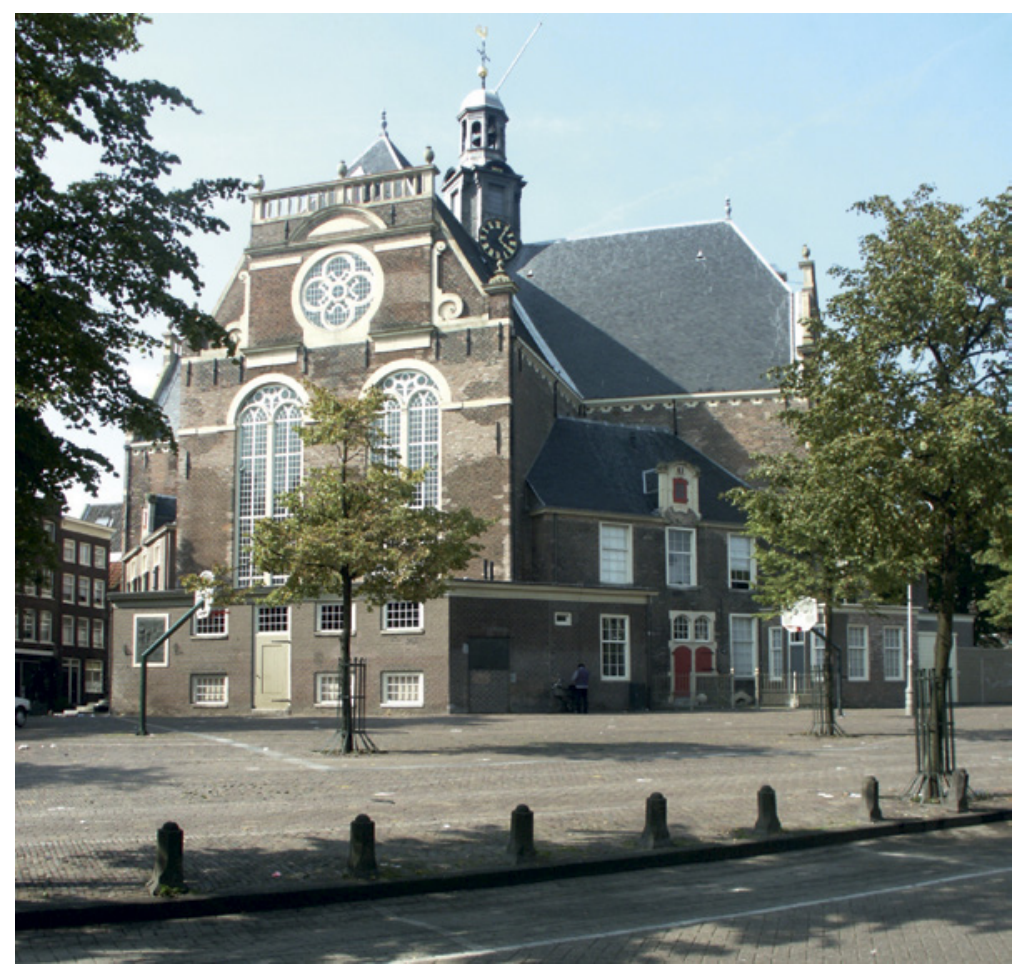

FIGURE 12.2 Hendrick de Keyser, Noorderkerk in Amsterdam (1620-1622) IMAGE (C) AUTHOR

service remained the nobility's chief vocation: the field commanders of the modern armies as they took shape in the sixteenth and seventeenth centuries were almost without exception sons of old chivalric families. In the meantime, however, castles had become hopelessly ill-suited to any serious defensive function, due to the development of potent artillery and modern military tactics; defence had long since become a function of dedicated modern fortresses instead. For noble families their ancestral castles did, however, remain a cherished prize possession, because their very age had become a measure of the importance of the family residing within. The old noble residences were of course often adapted to new tastes and requirements for luxury and presentability during the seventeenth and eighteenth centuries, but it was largely the interiors that were adapted. The exteriors remained deliberately as reminiscent as ever of the knights' castles of old, with moat, drawbridge and towers. Even if such a home was entirely renovated, one or more of its towers would at a minimum remain preserved as an express relic of the old castle. This was a pan-European phenomenon, seen particularly in districts where new stately 


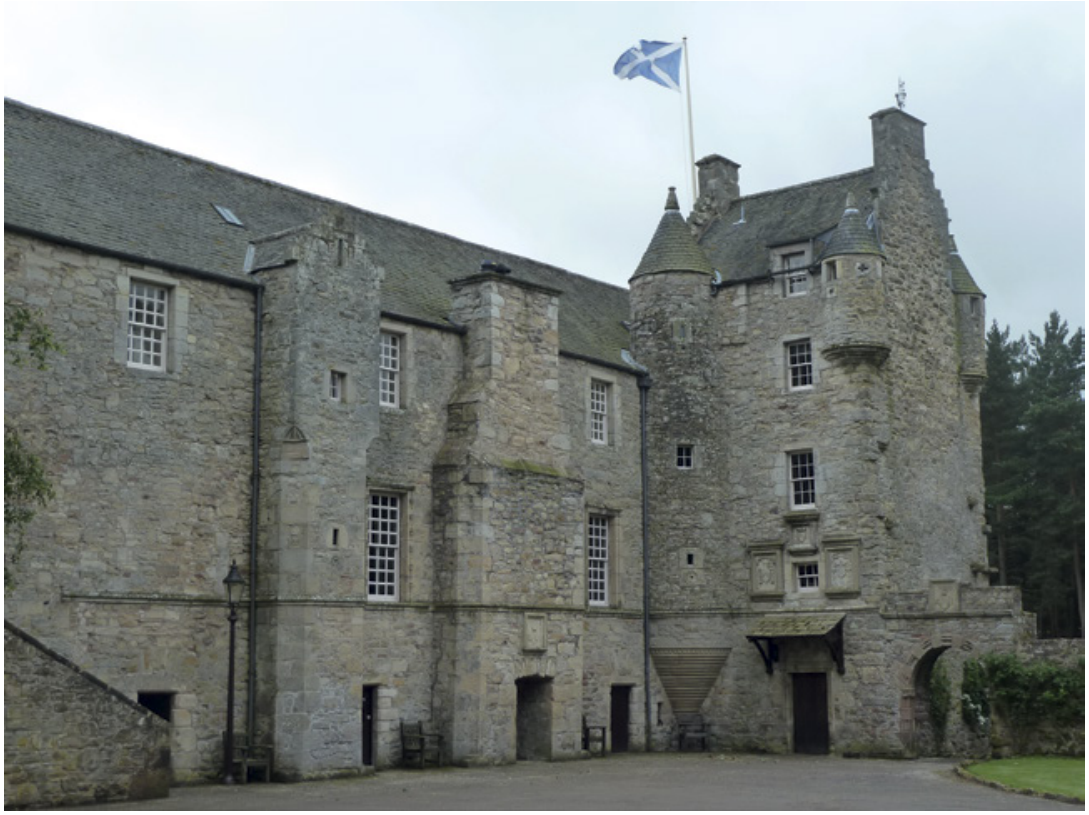

FIGURE 12.3 Ferniehirst Castle, Scotland, seat of the Kerr clan. Founded in 1470 but reconstructed in the late 16 th century

IMAGE (C) PUBLIC DOMAIN

homes for non-noble (or newly-ennobled) families came to be built alongside the old noble homes. ${ }^{7}$ These new families, typically merchants, bankers or lawyers, were often many times wealthier than the old gentry, a fact which they were only too pleased to show off. The only asset remaining to this established nobility to set clear water between themselves and the nouveau riche was the venerable antiquity of their lineage; and the chivalric origin of these families was first and foremost evident from the old-fashioned, military design of their homes. In 1632, a Scots knight, Sir Robert Kerr, warned his son, who was engaged in renovating the family castle, Ferniehirst, that he must retain the crenellation and towers, for the home must remain recognisable as a castle and it was these details in which the home's grace and nobility reposed [Fig. 12.3]:

7 Wemyss Ch., Noble Houses of Scotland (Munich - London - New York: 2014) 18-37, chapter "Ancestry and Architecture"; Olde Meierink B., "Conflict tussen oud en nieuw. De zeventiende eeuw", in Janssen H.L. - Kylstra-Wielinga J.M.M. - Olde Meierink B. (eds.), 1000 Jaar kastelen in Nederland. Functie en vorm door de eeuwen heen (Utrecht: 1996) 142-170. 
'By any meanes do not take away the battelment [...] for that is the grace of the house, and makes it looke lyk a castle, and henc so nobleste. ${ }^{8}$ By the same token, however, he advised his son to aim for the latest London or French tastes in the interior redesign. We see, then, that he was not concerned with evoking mediaeval associations in the interior but wished the exterior of his castle to exude a clear message to the world.

Something comparable was afoot throughout Europe: on every hand in the sixteenth and seventeenth centuries, old castles were being modernised, with deliberate preservation of a few external fortifications such as the moat, drawbridge, towers and/or battlements. The central residential tower in particular, known in French châteaux as a donjon and in German castles as a Bergfried, came to play a key role in this repurposing. ${ }^{9}$ In some cases, the family home was even a completely new build, yet with castle-like architectural elements applied. In all such instances, the antiquated military building forms were meant to express the connection with a (real or imaginary) chivalric past for the lord of the house and the nobility of his family.

This was commonly seen in the Dutch Republic of the Seven Provinces as it was elsewhere, and particularly in those provinces where the old gentry retained its social strength: the east-central provinces of Utrecht, Gelderland (Guelders) and Overijssel. ${ }^{10}$ The situation in the central province, Utrecht, lends itself especially well to further analysis, particularly in view of the detailed archival records which are preserved there. ${ }^{11}$

8 Letter of 20 December $163^{2}$ of Sir Robert Kerr to his son, Lord Lothian, on the rebuilding of Ferniehirst Castle. Laing D. (ed.), Correspondence of the Earls of Ancram and Lothian (Edinburgh: 1875) 64; Wemyss, Noble Houses 21.

9 For international comparisons, see, inter alia, Girouard M., Life in the French Country House (London: 2000) 54-65.

$10 \quad$ For Gelderland and Overijssel, see Olde Meierink B. - Storms-Smeets E., "Transformatie en nieuwbouw. Adellijke en burgerlijke buitenplaatsen in Gelderland (1609-1672)", in Kuiper Y. - Olde Meierink B. (eds.), Buitenplaatsen in de Gouden Eeuw. De rijkdom van het buitenleven in de Republiek (Hilversum: 2015) 180-207. Gevers A. -Mensema A. - Olde Meierink B., "Buitenplaatscultuur in Overijssel. Havezaten en spiekers in de zeventiende eeuw", in Kuiper - Olde Meierink, Buitenplaatsen in de Gouden Eeuw 210-235.

11 Ottenheym K.A., "Turm oder Portico? Die neuen Schlösser des Utrechter Adels im 17. Jahrhundert", in Hoppe - Müller - Nussbaum (eds.), Stil als Bedeutung in der nordalpinen Renaissance 377-399. 
The Utrecht nobility of the seventeenth century was organised in the ridderschap (Knightly Order), which also had representation in the province's political assembly, the States of Utrecht. Consequently, membership of the order was a sine qua non for an Utrecht nobleman if he wished a political career. Entitlement to admission to the order had been determined a century earlier, in 1536, by Emperor Charles v. The relevant legislation remained in force even after the abolition of Habsburg central authority. One of the requirements for admission to the Utrecht ridderschap was descent from an uncontested noble lineage and also the possession of an officially-acknowledged 'knightly castle' (ridderhofstede). A list of 59 such castles had already been drawn up in 1536 for these purposes. Only a few additional noble houses were subsequently formally acknowledged as a knightly castle, such as Amerongen in 1597, Broekhuizen in 1629 and Drakestein in $1642 .{ }^{12}$ The right to membership of the ridderschap and thus the key to political influence - was embedded in the possession of these houses. Nevertheless, only true noblemen could avail themselves of that right, which is why the ridderschap's meeting chamber had a chart on the wall giving the names of members of the order alongside, in each case, the name of their castle. ${ }^{13}$ As early as the beginning of the sixteenth century, such a knightly home was described as a fortified house replete with moat and drawbridge: 'which have fortifications and houses and drawn-up bridges'. Additionally, it was stipulated that any farming outbuildings (sties and barns) must be within the moat: 'That those constructions be within the compass of the knightly castles.' ${ }^{14}$ These outbuildings within the moat originally served, according to feudal usage, to offer the surrounding population, together with their livestock and harvested crops, a safe refuge in times of crisis. Later, they came to be used almost exclusively for the lord's own horses and to store the yield of his own estates, and later still, his coaches.

Evidently, a need was felt as the seventeenth century dawned to reassert the status quo. In 1608-1611, a register 'of the knightly residences and noble courts' in the Province of Utrecht was drawn up, distinguishing between three

\footnotetext{
12 Drie R. van, "Het begrip ridderhofstad in de 16de en 17de eeuw", in Olde Meierink B., e.a. (eds.), Kastelen en ridderhofsteden in Utrecht (Utrecht: 1995) 41-50.

13 See the heraldic chart of the ridderschap of Utrecht in Olde Meierink, Kastelen en ridderhofsteden in Utrecht, 48 and plate $\mathrm{i}$.

14 'die Vesten ende Huysen ende opgetogen Bruggen hebben', 'Dat die Bouwhuysen binnen het begryp vande Ridderhofsteden sullen zijn'. Citations of the legend on the heraldic chart of the ridderschap of Utrecht of 1674 . The same descriptions can be found on documents as early as 1512. Drie, "Het begrip ridderhofstad".
} 
categories: first, the true ancient castles, those founded prior to 1400 ('the oldest and true knightly fortresses'); second, castles of around two centuries old ('those which were known two hundred years ago and those which became known shortly thereafter'); and lastly, anything later in date than that. Houses in this latter category were meant to be labelled lodges or stone-built houses and could not lay claim to being a knightly castle ('those which are regarded as pleasure-houses or stone chambers'). ${ }^{15}$ The first category was made up of 36 homes, including Amerongen, Zuylenstein, Natewisch, Huis Doorn, Rijnhuizen, De Haar, Nijenrode, Oud Zuylen, Nederhorst and Loenersloot. There were 29 homes in the second category, including a number of castles along the Langbroeker Wetering, Kasteel Heemstede in Houten (already a ruin at that time), Oudaen in Breukelen, and Drakestein. The third category listed 28 houses, largely minor castles and country estates. Finally, a list was given of 14 dubious cases whose age presumably had proved impossible to determine, including Maarsbergen outside Doorn, Montfoort castle, and Huis Oudegein. The register also included castles which lay in ruins (these were labelled 'verdestrueert', i.e. 'destroyed'), since a knightly fortress retained its privileges even as a ruin. Thus, acquiring one of these and building a new house on the old foundations could enable the acquisition and reviving of the coveted privileges of a knightly castle.

The external hallmarks of a knightly home identified in the act of 1536 defensive build, moat, drawbridge and outbuildings on the keep - were basic features of most noble houses of the age [Fig. 12.4]. That being so, the description provided served as an early sixteenth-century reaffirmation of how things had always been prior to that. Although this law officially remained in force, later sixteenth- and early seventeenth-century practice was not so demanding when it came to the requisite external features. Only much later, around the midpoint of the seventeenth century, would this stipulation gain a new lease of life. Noblemen tackling a renovation of their residences in the early seventeenth century observed only the most essential parts of the 1536 regulations, such as the moat and the wooden drawbridge. In other respects, they sought to reflect the latest architectural insights as closely as possible, which from the 1630 s onwards was the Classicism introduced to the Northern Low Countries shortly before that decade by the Haarlem artists Jacob van Campen

15 Het Utrechts Archief [Archive of the City and Province of Utrecht], 233 (Staten van Utrecht 1581-1819), inv. no. 364-9-157. 'Van de ridder-woningen ende edele hoffsteden': 1) 'de audste ende rechte ridderhoffsteden'; 2) 'die over de 200 jaeren bekent sijn geweest ende cort daernaer bekent geworden sijn'; 3) 'die voor lusthuysen offte steene cameren geacht'. 


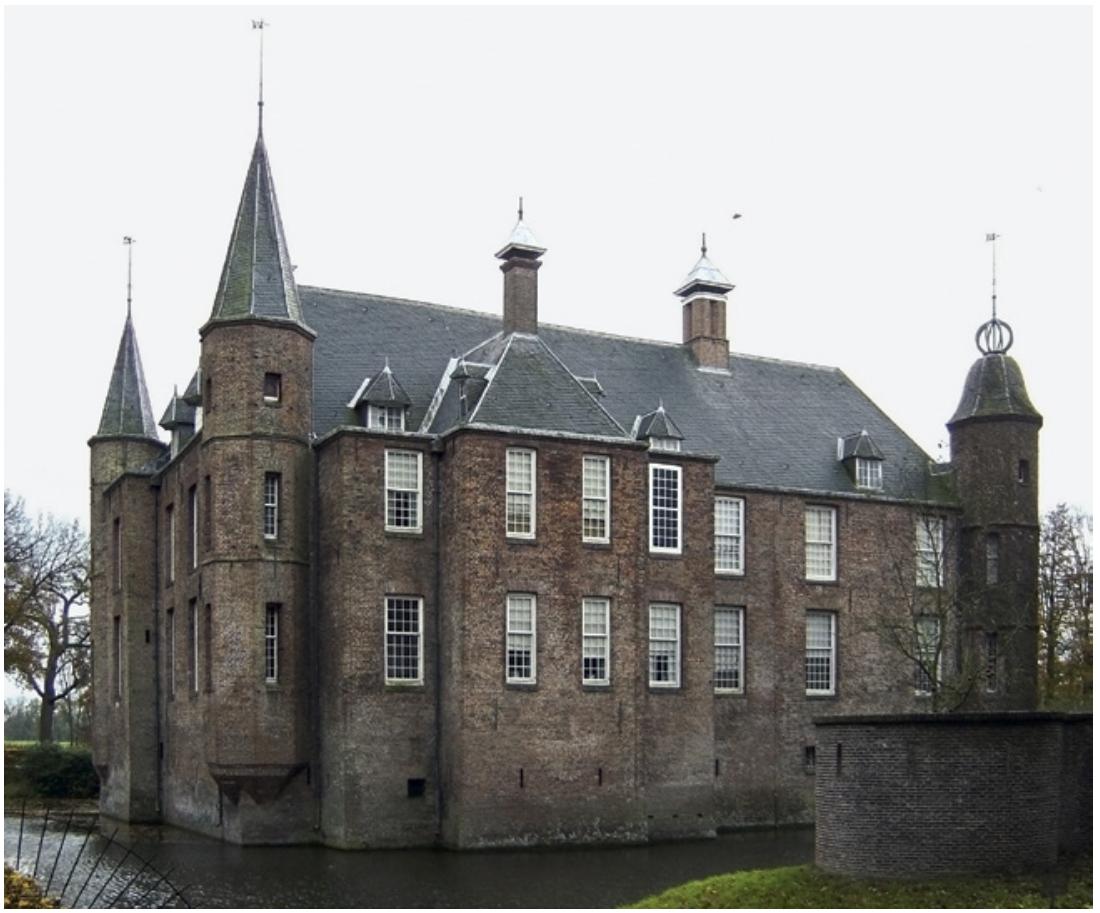

FIGURE 12.4 Zuylen Castle (Maarssen), seen from the North. Founded in the 13th century and several times enlarged and reconstructed. The northern walls date mainly from the $15^{\text {th }}$ and 16 th centuries IMAGE (C) MERLIJN HURX

and Salomon de Bray. Classicism also found its way into castle architecture at an early date. The first known example of its application in a nobleman's castle is the new wing (1629) of Kasteel Warmond, designed by Salomon de Bray for Jacob van Wassenaer. [Fig. 12.5]. This was a fairly self-contained component with no direct repercussions on the rest of the architecture in the older castle.

Once Classicism had found general acceptance at the court with the building of the Mauritshuis, Noordeinde Palace and other buildings in and around The Hague, the nobility throughout the Dutch Republic was not far behind. In the modernisation and extension programmes of the Utrecht knightly homes in the 1630s, the effect aimed at was to transform the old, castle-like exteriors into sharp, closed, regular architectural volumes. In this process, external hallmarks such as the moat and its drawbridge were retained, as was part of the old substance of the building. This would enable future generations to demonstrate that the new house was the legitimate successor to the 


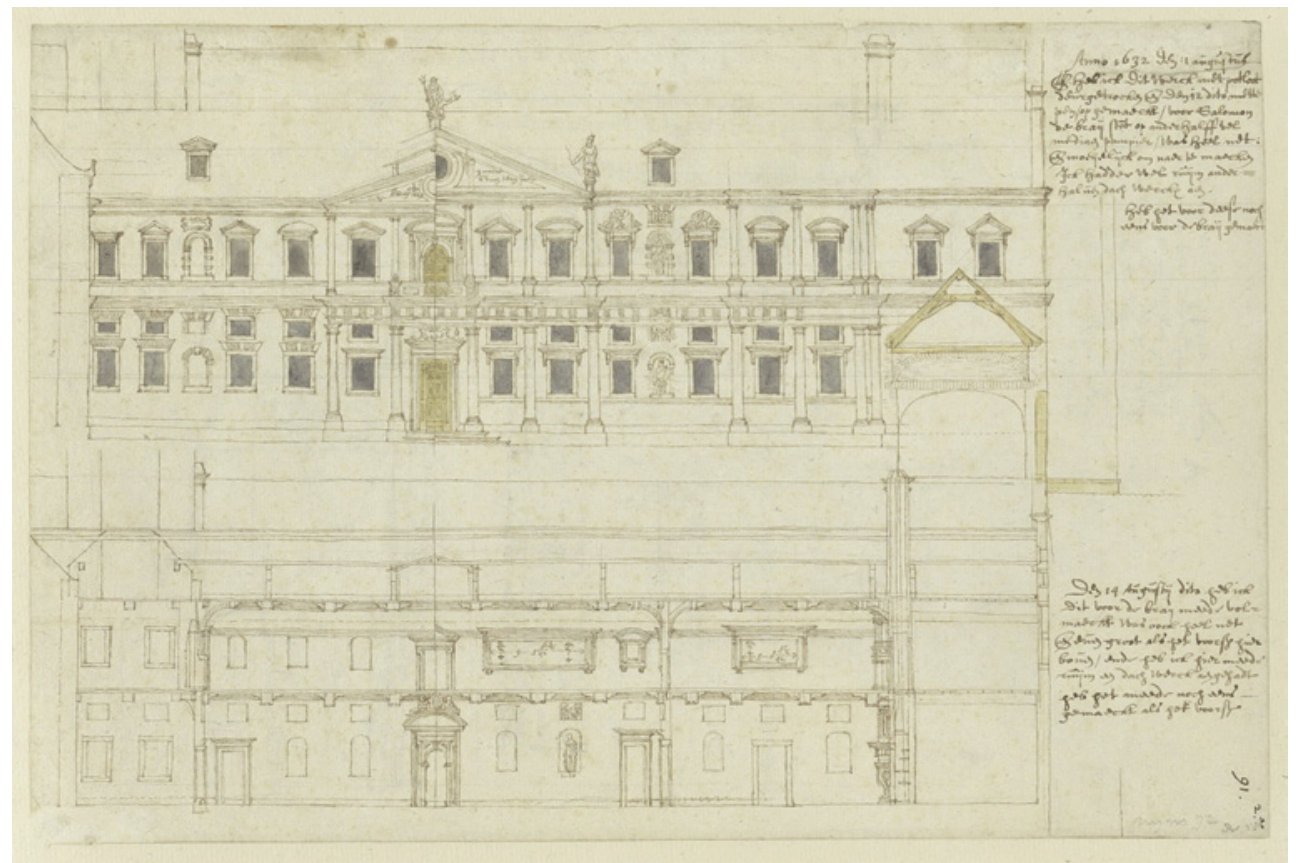

FIGURE 12.5 Warmond Castle. Design from 1629 by Salomon de Bray for a new entrance wing, showing two options for the central projection. Drawing by Pieter Saenredam (1632), $31 \times 20.4 \mathrm{~cm}$. See also Fig. 10.16 IMAGE (C) HAARLEM, NOORD-HOLLANDS ARCHIEF

old knightly castle. Evidently, it was felt sufficient for that purpose to leave part of the walling of the former towers visible at basement level, because in many cases nothing remains visible of the old masonry in the new exterior. Examples of such renovations are the knightly houses of Oudegein and Rijnhuizen. Oudegein was rebuilt around 1633 for Adriaan Ploos, Lord of Tienhoven. The base of the old stone residential tower was included in the cellar level of the new construction. ${ }^{16}$ The new house was given taut rectangular dimensions [Fig. 12.6]. The block is three storeys high and topped off with a shield roof. Apart from the lintels to the main entrance, which incidentally are not right in the middle of the side, there is no Classical ornamentation. That said, the general ideal of regularity and clarity of composition make this house a model of the sober, pilaster-free variant of Classicism. Rijnhuizen, a stately home outside Jutphaas near the city of Utrecht, is a comparable example, although the new

16 Bullinga N. - Kamphuis J., “Oudegein”, in Olde Meierink (ed.), Kastelen en ridderhofsteden in Utrecht $35^{6-359 .}$ 


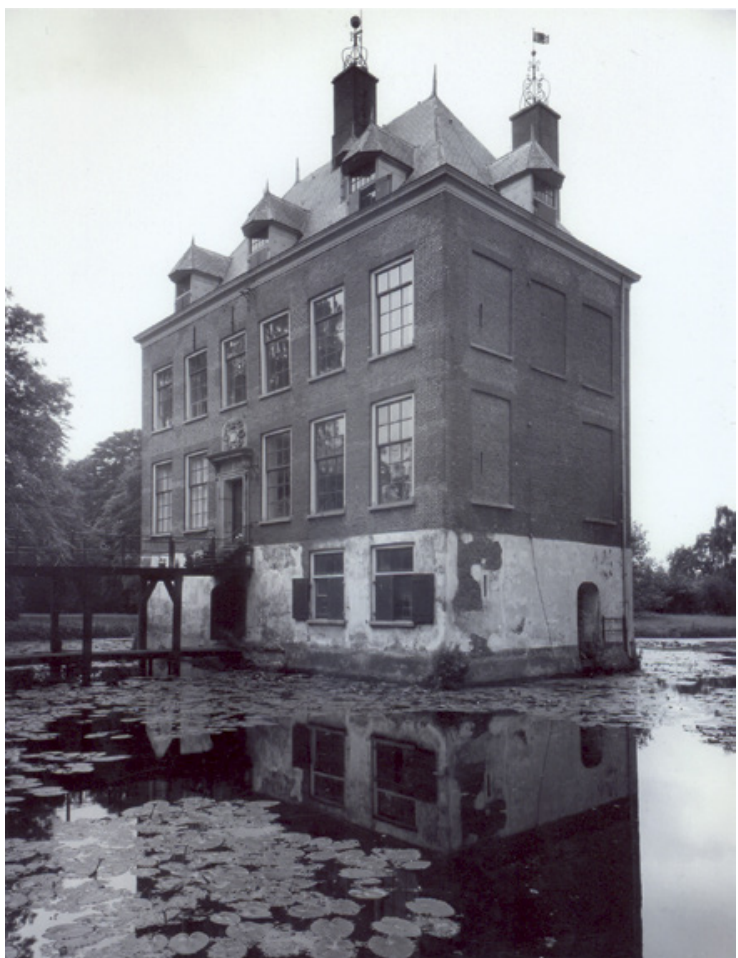

FIGURE 12.6

Huis Oudegein at Nieuwegein, built in 1633 on the remains of the former castle of the $13^{\text {th }}$ and 14th centuries IMAGE (C) RCE

architectural techniques were laid on far more heavily here [Fig. 12.7]. Reynoud van Tuyll van Serooskerke, who married Agnes van Reede of Drakestein in 1636, had the old Huis Rijnhuizen extensively remodelled around $1637 \cdot{ }^{17}$ Only in the basement were elements of the mediaeval house spared. What arose in 1637 was a much enlarged, almost square block with a high shield roof all around. The whole construction is in sober brickwork, and the front elevation is enriched with a central section crowned with a triangular pediment. All in all, the new exterior at Rijnhuizen is a sober, pilaster-free variant of the design of the Mauritshuis in The Hague.

\section{The Rise of Bourgeois Country Houses in the Province of Utrecht}

The Classical architectural style was also quick to start making an appearance in leading bourgeois circles from the 1630 s onwards. For instance, beginning

17 Olde Meierink B., "Rijnhuizen", in Olde Meierink, Kastelen en ridderhofsteden in Utrecht 391-395. 


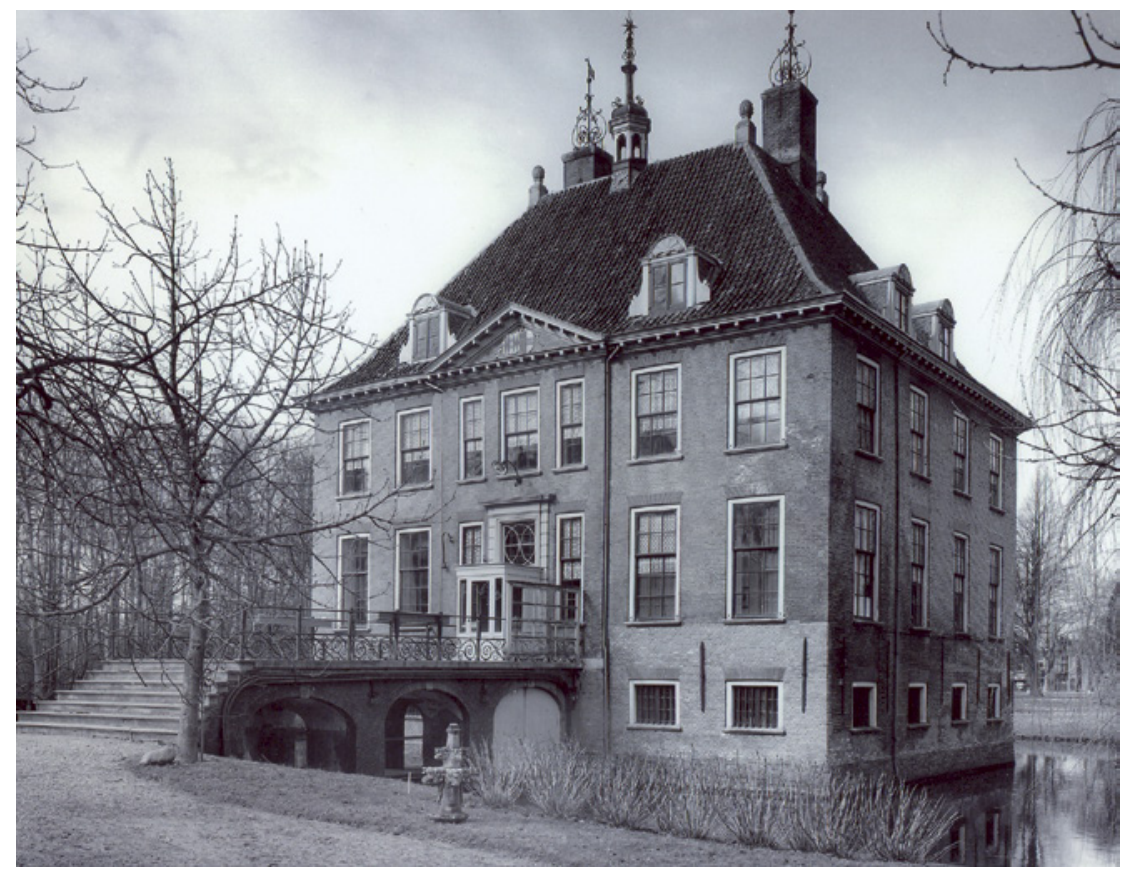

FIGURE 12.7 Castle Rijnhuizen at Jutphaas, built in 1637 as a classicist house on the foundations of a castle from the 14 th and $15^{\text {th }}$ centuries IMAGE (C) RCE

in 1637, Philips Vingboons designed homes in the style for wealthy merchants and highly-placed politicians in Amsterdam. For the same group of clients, he also developed numerous country estates, both in the polders of Noord-Holland and along the River Vecht, which was an increasingly tempting place for Amsterdammers to buy property in at this time. ${ }^{18}$ Occasionally from the 1620s, and systematically and at scale from the 1630 onwards, Amsterdammers invested, speculated and built along the River Vecht in the neighbouring Province of Utrecht. One of the oldest preserved examples of one of these vacation houses is Huis ten Bosch outside Maarssen, built in 1628 for the Amsterdam merchant Pieter Belten by Jacob van Campen [Fig. 12.8].

18 Wyck H.W.M. van der, De Nederlandse buitenplaats. Aspecten van ontwikkeling en herstel (Alphen a.d. Rijn: 1983) 29-40. Meischke R., "De ontwikkeling van de buitenhuizen aan de Vecht”, in Munnig Schmidt E.- Lisman A.J.A.M. (eds.), Plaatsen aan de Vecht en de Angstel (Alphen a. d. Rijn: 1985) 7-24. Verschuure-Stulp G. - Renes H., "Hollandse buitenplaatsenlandschappen. Buitenplaatsen en hun relatie met het landschap (16o9-1672)", in Kuiper Olde Meierink (ed.), Buitenplaatsen in de Gouden Eeuw 42-65. 


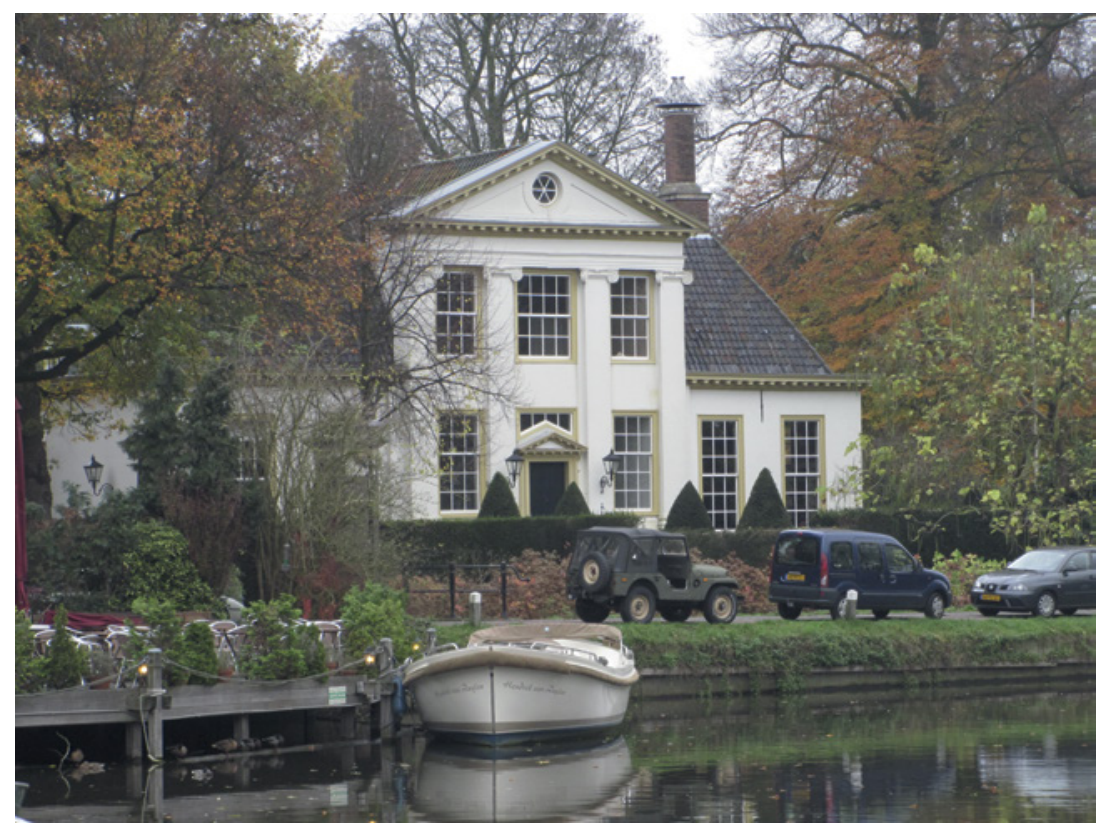

FIGURE 12.8 Huis ten Bosch at Maarssen, the country house of the Amsterdam merchant Pieter Belten (1628), designed by Jacob van Campen IMAGE (C) AUTHOR

It is the first example in the United Provinces of an attempt to evoke the idiom of the Venetian villa at local scale.

The colonisation of the Vecht District by the great and good of Amsterdam can be closely traced by following the business operations of the senior Amsterdam politician Joan Huydecoper and his architect Philips Vingboons around Maarsseveen. ${ }^{19}$ Huydecoper was a brother-in-law of Pieter Belten, whose second home Huis ten Bosch (1628) in Maarssen was. Huydecoper owned Goudenstein, a country estate north of Maarssen. Between 1626 and 1628, he converted this farmhouse into a stylish retreat. In 1645, Philips Vingboons added a completely new wing to the rear. Until his death in 1661, Huydecoper continued to purchase land in and around Maarsseveen to develop and sell on new country estates at a fat profit. He bought up fields, sometimes with an old farmhouse still on them, improved the ground by having drainage channels dug, and planted orchards. He would then sell the plots to Amsterdammers in search of a suitable location to get out of the city. The oldest example of this business model is Elsenburch, directly abutting Goudenstein,

19 Ottenheym K.A., Philips Vingboons (1607-1678). Architect (Zutphen: 1989) 34-45. 
which was planted up from 1633 onwards and sold on in 1637. In the same year, Philips Vingboons built Elsenburch on the plot for the new owner. Over fifteen such projects of Huydecoper's from the ensuing years are known. It is even known in one case that he delivered the blueprint for the country house to be built when selling the plot. The designs were sometimes by Vingboons or Huydecoper himself, an avid architectural draughtsman. So it was that one long chain of gardens, orchards and country houses arose in the meadowland along the Vecht and the land behind its banks in the 1640 s and 1650s, most of these houses adorned with a pediment or other Classical hallmarks.

The old nobility will have been none too pleased to see the vistas to and from their redoubtable ancient castles, which had dominated the countryside since time immemorial, more and more choked up with all these Classicist nouveau-riche playgrounds. Worse still for them, the newly wealthy bourgeoisie's rise was expressed in other ways besides the building of country estates: they sought to appropriate ever more of the political and legal privileges which had always been regarded as the preserve of the nobility. Joan Huydecoper's business activities, to stick with that example, illustrate the upcoming bourgeoisie's aspirations of achieving near-noble status. Huydecoper had been knighted by the Swedish Crown in 1637 , a title which was only allowed to be used as a nobilitas diplomataria in the Dutch Republic, with no particular privileges appended to it. ${ }^{20}$ That same year, Huydecoper bought the squiredom (heerlijkheid) of Tamen and Blokland in Utrecht to bolster his legal standing in that province. The Utrecht aristocracy set determinedly about keeping this parvenu out of their orbit, and managed to have the States of Utrecht overturn the purchase in $1639 .{ }^{21}$ In 1641 , however, Huydecoper did manage to become Lord of Maarsseveen, and only after this was his estate development business really able to prosper.

\section{5}

\section{Revival of Interest in Old Traditions}

In the provincial government of Holland, there was no contesting the might of the top layer of bourgeoisie, who approached regent-like status. Here even in the countryside, the sway of the bourgeoisie was penetrating further and

$20 \quad$ Aalbers J., "Geboorte en geld. Adel in Gelderland, Utrecht en Holland tijdens de eerste helft van de achttiende eeuw", in Aalbers J. - Prak M. (eds.), De bloem der natie. Adel en patriciaat in de Noordelijke Nederlanden (Meppel - Amsterdam: 1987) 56-78 (esp. 62-64).

21 Eeghen I.H. van, "Wee het Landt daer Godtlose Rechters sijn!' Of: Joan Huydecoper, Heer van Tamen en Blokland", Maandblad Amstelodamum 63 (1976) 11-12. 
further. On the other hand, in the Republic's eastern provinces, Gelderland and Overijssel, there was no pressure worth mentioning upon the nobility's control of the countryside, because there the bourgeoisie was far less powerful and obstreperous than in the urbanising west. At both extremes of the Republic Holland and the eastern provinces - rural architecture was in Classicism's debt, whether in the bourgeois country houses or in the renovated noble residences. Philips Vingboons, for instance, was much in demand as an architect for eastern noblemen as well as for well-heeled Amsterdammers seeking a retreat in the new polderland of Noord-Holland and along the Vecht. Among his designs are Vanenburg in the Gelderland district of Veluwe; the noble houses of Harsvelt, Peckedam and Nijenhuis in Overijssel; and Nittersum Castle in the north-eastern province of Groningen. For these clients, all renowned old members of their respective provincial knightly orders, Dutch Classicism as pioneered by van Campen and his imitators was evidently the most straightforward way of demonstrating status and ambition.

In Utrecht Province, which formed the intermediate zone between Holland and the eastern provinces, a particular status had arisen which may be explicable from the confrontation between the west's urban bourgeois culture and the traditional, more feudal social fabric in the east of the Republic. The privileged position of the Utrecht nobility, which for long ages had been comparably grand with that of their counterparts further east, was increasingly squeezed out by the nouveau riche from about 1640 onwards. While the pre-eminent bourgeois families wished to give themselves airs and graces in this era with foreign titles and invented family trees, the real members of the nobility felt an increasing need to set clear blue water between themselves and bourgeois upstarts. ${ }^{22}$ Money and possessions were no longer a domain in which they could set themselves apart from the arrivistes, but their families' antiquity and chivalric descent did remain as their last weapon. This requirement, particularly in the Province of Utrecht, made these families' need for authentic antiquity a very current topic in the period. Prince Frederick Henry had already ordered in 1640 that the ranks of the Utrecht knightly order (ridderschap) must be swollen with new members. This had given rise to a nigh free-for-all, with some applicants seeking to obtain noble status with forged papers. The increasing desire for distinction led to more flaunting of age in all types of expression,

22 Kooijmans L., "Patriciaat en aristocratisering in Holland tijdens de zeventiende en achttiende eeuw", in Aalbers - Prak, De bloem der natie 93-103. Bok M.J., "Laying claims to nobility in the Dutch Republic: epitaphs, true and false", in Eck X. van - Hecht P. (eds.), Ten essays for a friend: E. de Jongh 65, Simiolus 24, 2/3 (1996) 107-124. 
such as memorial plaques in churches and family portraits depicting coats of arms and illustrious ancestors.

In architecture, this situation revived the significance of the old edicts from the reign of Emperor Charles v. After all, for admission to the order, it was not sufficient to prove one's family's nobility; the chivalric origin of the residence also had to be demonstrated. The edict of 1536 required that the knightly castles have a defensive character and expressly stipulated the presence of a moat, drawbridge and buildings within the defensive structures. These components never completely fell into desuetude, and they are found even in those buildings conceived as a ridderhofstad which were designed or remodelled in a more Classical style. To emphasise the chivalric character of the buildings even more, a new major mark of identification was added to the standard set without ever having been ordained as such by law: the tower, symbol par excellence of nobility. ${ }^{23}$ The defensive tower, or donjon, was a fortress' last redoubt and thus the place where family treasures and archives had by tradition always been kept. Even long after the donjon's military significance had been rendered outdated by modern techniques of warfare, the great tower remained a beloved motif all over Europe in the construction of new noble and royal residences in the countryside. The association of an old tower with chivalric family roots is also clear from the degree of circumspection with which old castle towers surviving from the ancestral fortress were applied in their new contexts. Well-known examples of this in the Low Countries would be the castles of Rosendael, outside Velp, and Rechteren, outside Dalfsen. Not infrequently, these towers were further heightened in the seventeenth century, as at Rechteren and Hoensbroek Castle in southern Limburg [Fig. 12.9]. Reuse of an old tower, extension of an old tower and the construction of a new tower were all strategies employed. Towers were invoked repeatedly to emphasise the chivalric origin, and thus the nobility, of the owning family.

In the Province of Utrecht, we see a keenness for prominent towers as far back as the 1630s, such as in the cases of Kasteel Zuylenstein near Leersum, which was extensively modelled for the stadholder, Frederick Henry, in 16321633 with a substantial raising of the tower, and of Nederhorst den Berg, to which four hexagonal corner turrets were added in $1635 .{ }^{24}$ The mediaeval knightly castle of Drakestein was completely modernised, presumably in the

23 Olde Meierink B., "De grote toren: een adelssymbool?", Virtus. Bulletin van de werkgroep Adelsgeschiedenis 4 (1997) 1-10.

24 Meischke R., "Het kasteel Zuilenstein te Leersum", in Hoekstra T.J. - Janssen H.L. Moerman I.W.I. (eds.), Liber castellorum. 40 variaties op het thema kasteel (Zutphen: 1981) 270-278. Bosch van Drakestein R., "Zuilenstein", in Olde Meierink Kastelen en ridderhofsteden in Utrecht $5^{22-526 .}$ 


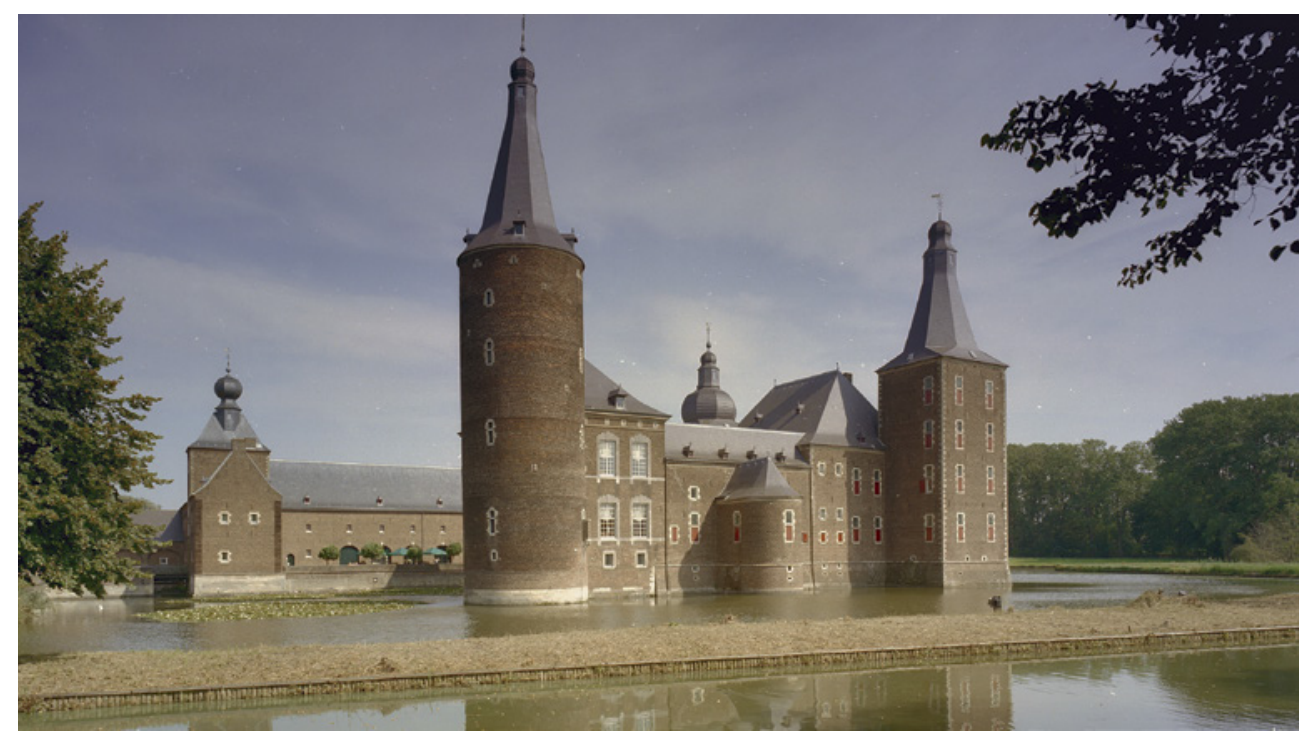

FIGURE 12.9 Hoensbroek Castle. The medieval castle has been rebuilt in 1643-1656 by the architect Matthieu Dousin. The main tower from 1360 was consciously maintained and even enlarged by a new, high spire.

IMAGE (C) RCE

early 1640 s, for Gerard van Reede. ${ }^{25}$ The new Drakestein is a regular octagonal building rising tower-like from the water [Figs. 12.10a, b]. The new octagonal building plan is redolent of an old donjon. However, the main entrance was enriched in Classical style with a monumental temple façade of four tall Ionic pilasters. This put Drakestein in the group of new, Classicist castles. The towerlike quality of the building is in fact restricted to the exterior only, for on the plans the interior is not subdivided on the basis of octagonality. The interior consisted of a sequence of handsome halls and chambers just as could be found in the era's Classical villas. The only difference is that here, all four corners are bevelled so as to lend the building its characteristic octagonal profile.

Kasteel Heemstede outside Houten, built in 1645, marks a new stage of this development. ${ }^{26}$ The old house 'Heemstede', presumably built circa 1400, was officially acknowledged as an Utrecht knightly fortress by Emperor Charles V in 1536; by the mid-seventeenth century, it was looking fairly down at heel.

25 Olde Meierink B., "Drakestein", in idem, Kastelen en ridderhofsteden in Utrecht ${ }^{175^{-179} .}$

26 Lisman A.J.A.M., Heemstede, gelegen in de provincie van Utrecht (Alphen a.d. Rijn: 1973). Wyck, Nederlandse buitenplaats 157-175. Wevers L., Heemstede. Architectonisch onderzoek van een zeventiende eeuwse buitenplaats in de provincie Utrecht (Delft: 1991). 


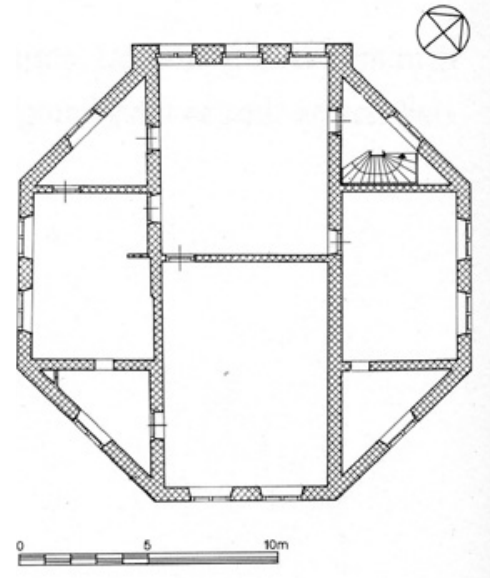

\section{FIGURE 12.10A}

Drakestein at Lage Vuursche, built in 1640-1643 as a classicist house in the shape of an octagonal tower. Its medieval predecessor was situated elsewhere on the grounds. Drawing R.G. Bosch van Drakestein.

IMAGE (C) B. OLDE MEIERINK ET AL., KASTELEN EN RIDDERHOFSTEDEN IN UTRECHT (UTRECHT: 1995) 178

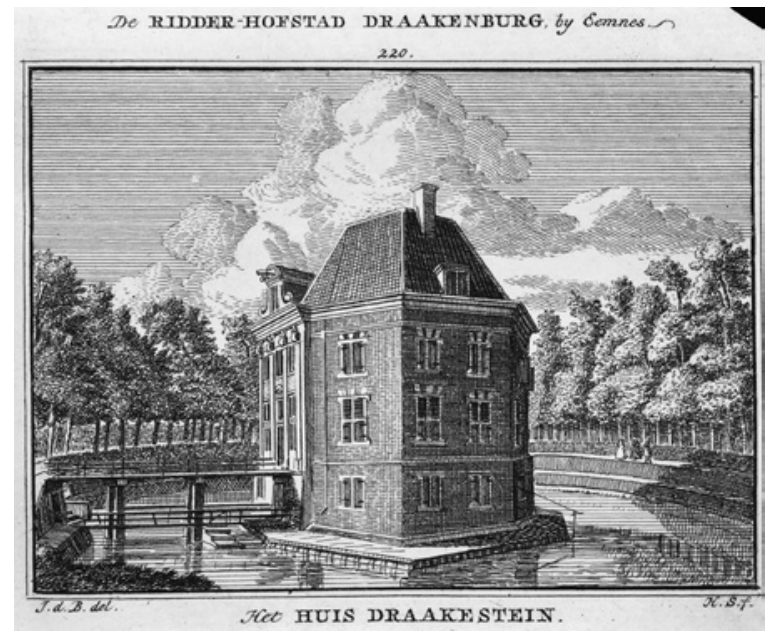

FIGURE 12.10B

Drakestein. Engraving by Hendrik Spilman (circa 1747) after Jan de Beyer IMAGE (C) RCE

The heirs, one Pieck and his wife (of the van Winssen family), decided not to incorporate the old ruin into the new house but rather to build a completely new castle a short distance away. Over the previous few decades, a number of existing knightly fortresses in the district had also been largely renovated, but in those cases the foundation of the old house, or a few surviving walls, were without fail and very deliberately incorporated into the new design. This was to ensure the continuity of chivalric status and the special privileges appended to it, such as membership of the ridderschap of Utrecht. Although the new Heemstede of 1645 did not rise upon the foundations of the old house, one gains the impression that the exterior of the new house was very much 
intended to express that it was the legitimate successor of the old knightly fortress [Figs. 12.11a, b].

Heemstede is a near-square house surrounded by a wide moat. In addition, its forecourt with outbuildings had its own narrow moat. The new castle is dominated by the central square tower with pyramidal roof, crowned with a monumental star-shaped chimney. This tower surges up out of a square construction with corner turrets, each with a spindly pinnacle. The entire house is executed in understated brickwork; only the entrance is ornamented with a sandstone gate with half-columns. The four corner turrets and the central tower determine the whole profile, which echoes that of a mediaeval strongholt. Allusions to mediaeval defensive architecture are also seen in smaller external details, such as the defensive-looking bay window above the front door. That front door is itself very self-consciously massive and solid in execution and is peppered with rough iron rivets. The moat setting completes the picture of a castle, with an older square donjon at its heart. In this manner, Heemstede seems to be a seventeenth-century interpretation of the older kind of castle seen in the environs of Utrecht. ${ }^{27}$

Yet all of this was nothing more than carefully-concocted décor for public consumption and had little to do with the building plan itself; the interior was apportioned to satisfy the contemporary desire for refinement and comfort.

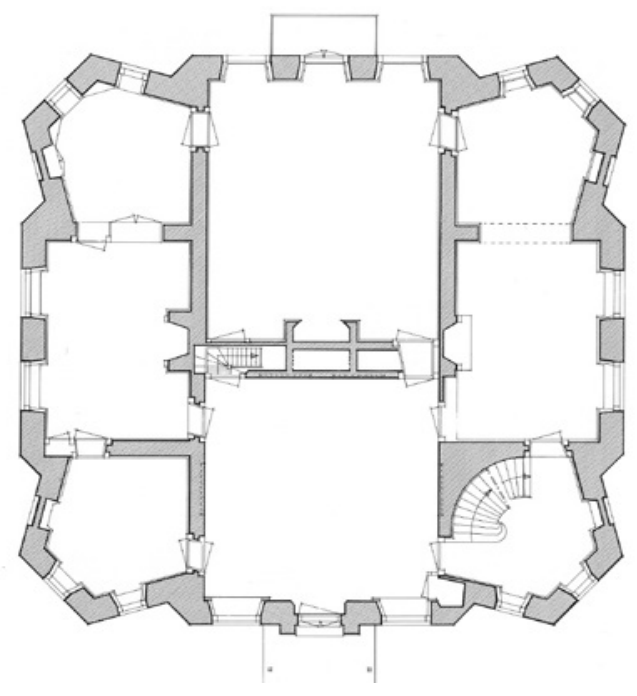

FIGURE 12.11A

Heemstede castle at Houten, built 1645 some hundred meters from the ruin of its medieval predecessor. Drawing R. G. Bosch van Drakestein IMAGE (C) B. OLDE MEIERINK ET AL., KASTELEN EN RIDDERHOFSTEDEN IN UTRECHT (UTRECHT: 1995) 248

27 Den Ham, Sterkenburg and Hinderstein, for instance, were castles arranged around a tall square donjon, whereas Oud Zuylen has four striking, slim, octagonal corner turrets rising clear of the roof and largely determining the profile. 


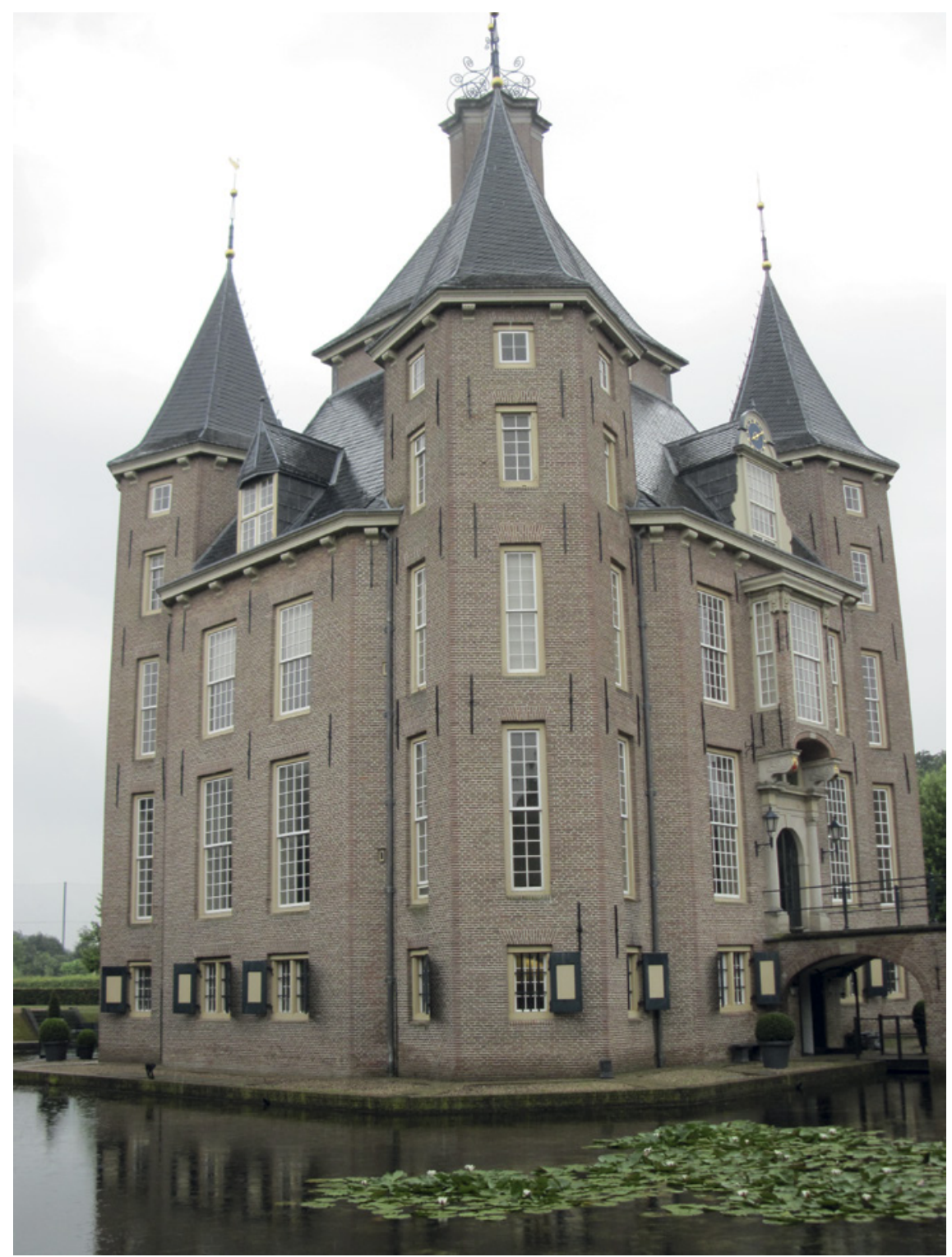

FIGURE 12.11B Heemstede castle IMAGE (C) AUTHOR 
Despite what the external profile might suggest, the house was not designed around a central tower but rather has two large spaces at its middle and a series of smaller rooms along the sides. The central square tower which seems to dominate the whole building on the external side is not in fact the kernel of the house but only a modest, light brick-and-wood construction resting on the tall roof structure. The tower space cannot be detected in the storeys below; we have in fact to do with a kind of rooftop belvedere. All in all, this new castle both satisfies the old requirements of 1536 with its moat, drawbridge and outbuildings and also meets the contemporary need for striking towers, achieving all this in a compact overall form designed in accordance with the rules of Classicism, with a dominant central axis and a strictly-regular distribution of windows across the faces.

After Heemstede, there followed Kasteel Renswoude, built for Johan van Reede circa $1654 .^{28}$ The architect is unknown. This is a completely new building, with at most parts of the foundations of the mediaeval precursor structure having been reused. ${ }^{29}$ The houses' mediaeval past is nevertheless emphatically expressed by this tall central tower and the pair of towers at the sides. At Renswoude, the house's chivalric character is restricted to the front view alone [Figs. 12.12a, b]. The rear elevation is accentuated by a central section with triangular pediment, entirely in keeping with Classical idiom [Fig. 12.12c]. The building plan is strictly symmetrical, with a vestibule and main staircase along the central axis and, on each storey, a pair of mirror-image apartments to the left and right of that core. In the case of Renswoude, the "archaic" character of the building profile is absolutely not the result of any provincialism or lack of awareness of the latest developments. After all, only a few years earlier the same client had retained no less a figure than Jacob van Campen as architect of the new church at Renswoude, designed in accordance with the most modern understanding of Classicism. The client's decision in 1654 to build what almost amounted to a donjon must therefore have been a considered choice.

\section{6}

\section{Bourgeois Castles}

The status which possessing an old castle or new "chivalric" house lent to its owner also appealed to the bourgeois élite and political leaders (regenten). They, too, considered that while a country house was a fine possession, a real

28 Schaik J. van, "Renswoude", in Olde Meierink Kastelen en ridderhofsteden in Utrecht 363-369.

29 Judging by the minor irregularities in the plan of the new central tower. 


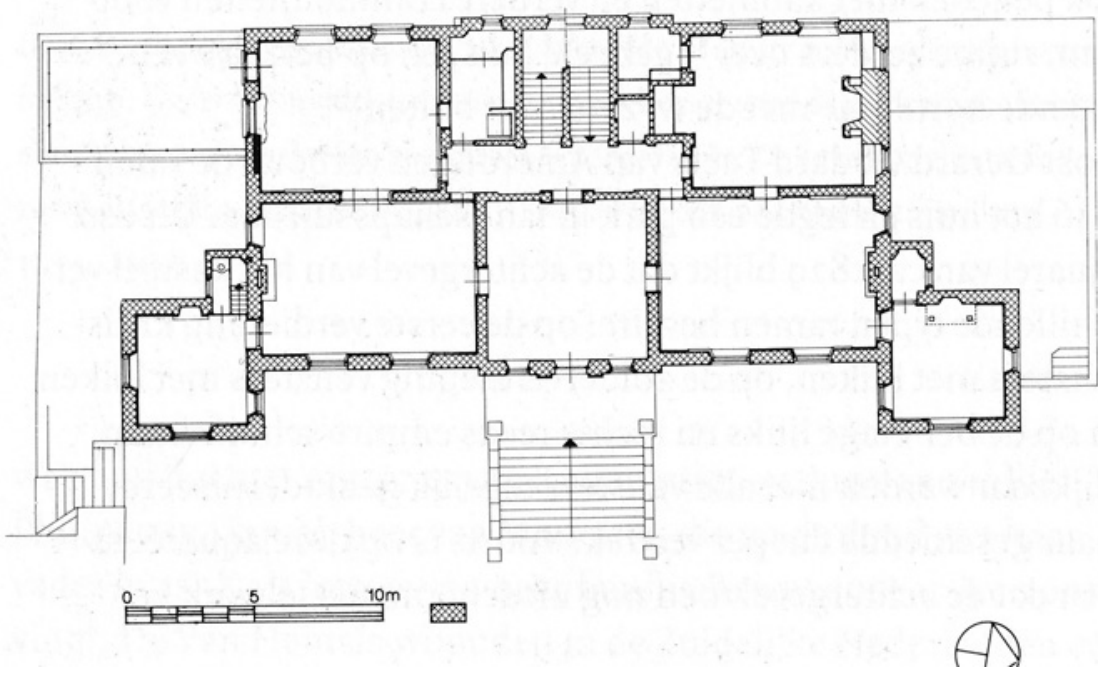

FIGURE 12.12A Renswoude castle, built in 1654 probably on the foundations of its medieval predecessor. Drawing R.G. Bosch van Drakestein IMAGE (C) B. OLDE MEIERINK ET AL., KASTELEN EN RIDDERHOFSTEDEN IN UTRECHT (UTRECHT: 1995) 178

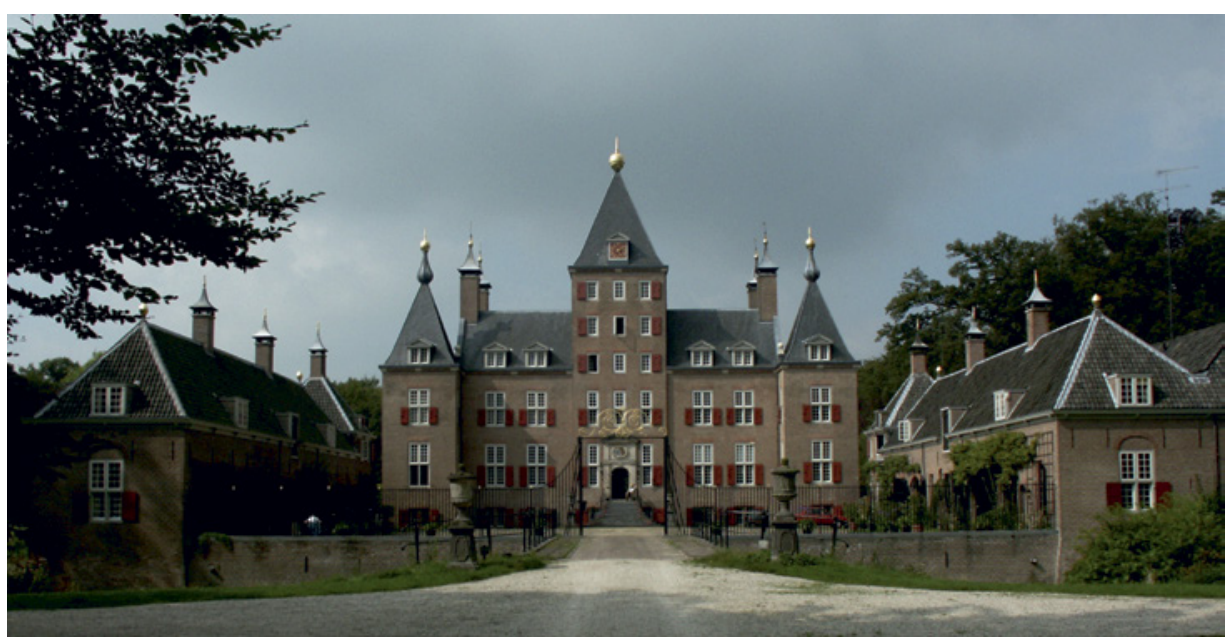

FIGURE 12.12B Renswoude Castle, front IMAGE (C) STEPHAN HOPPE 


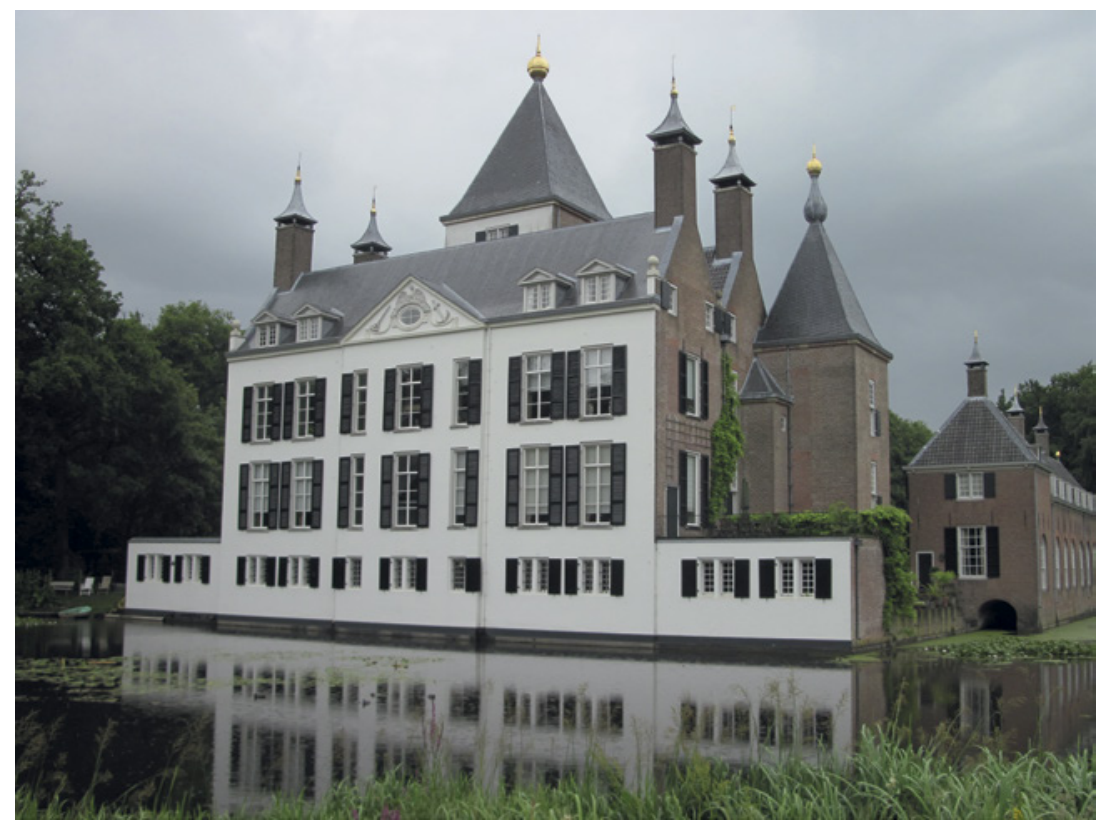

FIGURE 12.12C Renswoude Castle, rear facade, plastered in the early 19th century IMAGE (C) STEPHAN HOPPE

castle was a much better bet. While the nobility sought to outdo the bourgeoisie by flaunting antiquity, some leading burghers sought to wrap themselves in a fake cloak of age. The key bourgeois politicians of the United Provinces were able to buy a real castle with its concomitant lordship rights in order to wrap their new public standing with fitting old titles, heretofore the preserve of noblemen. When the Catholic nobility of the Southern Netherlands regained free access to their northern possessions during the Twelve Years' Truce (16091621), most of them decided not to return to rebel territory but rather to sell off their castles in the Republic to the highest bidder. This was how Johan van Oldebarnevelt, the State Pensionary, acquired Gunterstein in 1611, a castle still mediaeval in form at that time. Adriaan Pauw, a successor of his in that office, obtained the castle of Heemstede outside Bennebroek (in Noord-Holland) by purchase in 1620 and had it redone in more "chivalric" style, with two tall corner turrets. ${ }^{30}$ Constantijn Huygens, determined not to be outshone, bought his own old castle, Zuylichem, in the Bommelerwaard district, in 1630, and from then on was able to style himself 'Lord of Zuylichem'. Van Oldebarnevelt, Pauw

$30 \quad$ Boer H.W.J. de - Bruch H., Adriaan Pauw (1585-1663). Staatsman en ambachtsheer (Heemstede: 1985) 21-28, 63-70. 
and Huygens, like other senior diplomats of their age, had acquired a range of foreign noble titles too, partly by purchase and partly from the grace and favour of the rulers whose courts they visited. Although a foreign knighthood did not admit one to the knightly orders of the Republic, the purchase of a real castle sat well with the bourgeois élite's determination to approach an aristocratic lifestyle as closely as possible.

In a few instances where there was no old barony with concomitant castle, people even built a castle from scratch. Volcker Overlander, the most powerful Amsterdam politician of the first decades of the seventeenth century, obtained the village of Ilpendam and its environs from the heirs of the Count of Egmond in 1612. In 1618, he also acquired the rights of the lordship of Ilpendam, but there had never been a castle. Therefore, in 1622 Overlander had one constructed, which he called Ilpenstein, with ostentatious use of mediaeval elements such as battlements, corner turrets, moat and drawbridge [Fig. 12.13] ${ }^{31}$

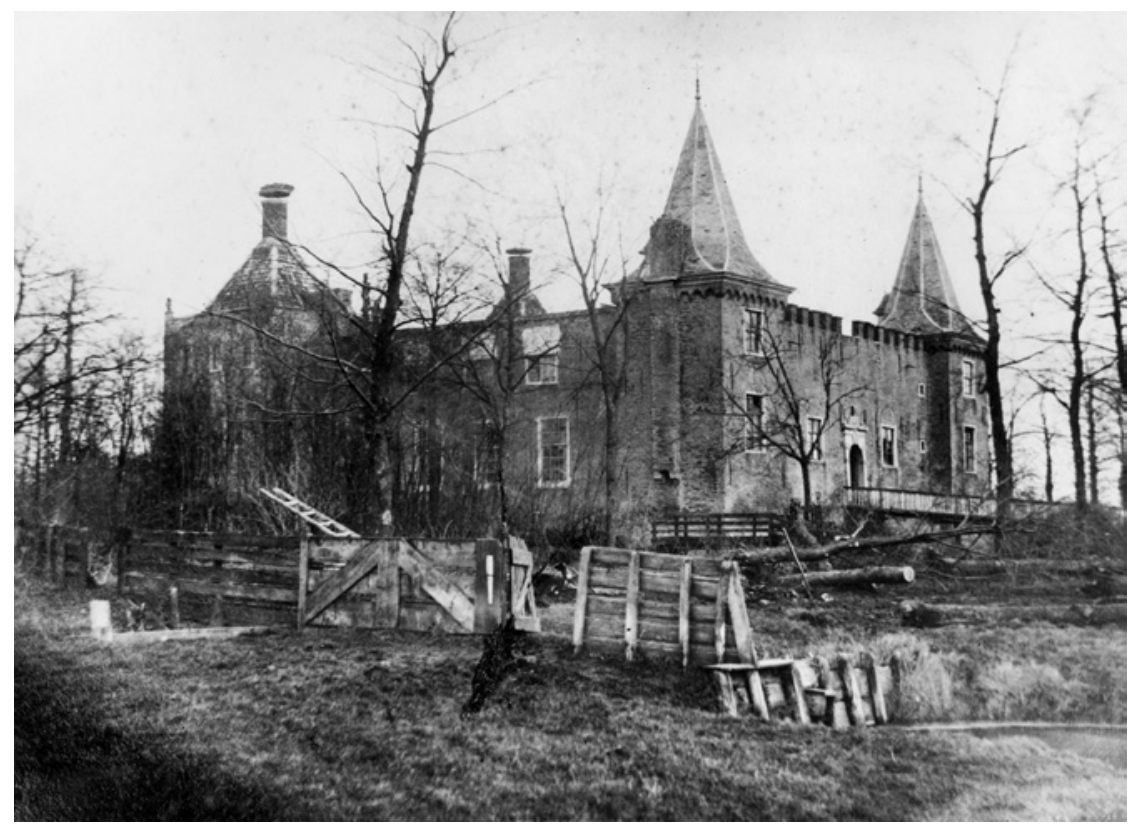

FIGURE 12.13 Huis Ilpenstein, a country house near Purmerend, built in 1622 as a mock castle. Photo taken shortly before its destruction in 1872 IMAGE (C) NOORD-HOLLANDS ARCHIEF, HAARLEM

31 Ernst Koning G. van, Het Huis te Ilpendam en deszelfs voornaamste bezitters (Amsterdam: 1836). In the mid-seventeenth century, Ilpenstein was owned by the powerful de Graeff, a family of Amsterdam burgomasters. 
Such bourgeois new castles were also rising from the ground in the Province of Utrecht in the mid-seventeenth century. Since 1640, interest in the old stipulations for a knightly fortress had been consistently growing there. A few instances are known of burghers who were so full of noble pretension that they had a new "chivalric" residence built; examples in Utrecht include Oud-Wulven and Linschoten. Johan van Toll, a wealthy burgher of Utrecht, purchased the lordship of the ambacht (amt) of Oud-Wulven in 1634 and had a new country estate built there in 1635 . Despite its modest dimensions, this house was not without its aspirations. The square house, with stair tower to the side, was made to look as though it was built on an old motte (castle hill). In reality, the house stood at the same level as any other local building, but a heavy dollop of earth had been slung at the ground floor to achieve the effect of a raised house. Johan van Toll may well have been seeking to give out that he was a descendant of the mediaeval noble van Toll family, which had died out in the sixteenth century. If so, Huis Oud-Wulven was an attempt to bolster that claim. ${ }^{32}$

In 1633, Johan Strick bought the farmhouse and lordship rights of Linschoten, and in 1637 he had a country home built there even though there was no formal knightly fortress. ${ }^{33}$ Strick had been entered on France's list of nobility as an esquier by Louis XIII in 1634. Yet neither the lordship of Linschoten nor this French rank entitled him to membership of the Utrecht ridderschap. In fact, Strick had little need of that anyway, for he was already a member of the States of Utrecht. His son Johan Strick jr. married the noblewoman Christina Taets van Amerongen in 1647 and it was he, more than his father, who will have needed the title in order to be accepted as an equal by his in-laws. With this in mind, Strick had Huis Linschoten extended around 1648 with all the hallmarks of a real knightly castle [Fig. 12.14]. This project doubled the size of the house by adding a new wing to the rear, including the great hall. The front was ornamented with two high, narrow corner turrets, and the entire house had a moat dug around it, so that it now truly stood surrounded by water as a real knightly fortress would. This was all mere outward show; the house was never acknowledged as an official ridderhofstede, and Strick van Linschoten was not admitted to the order of Utrecht nobility.

32 Olde Meierink, Kastelen en ridderhofsteden in Utrecht 542.

33 Reinink W.A. (ed.), Landgoed Linschoten (Bussum: 1994). Schaik J. van, "De bouwhistorie van het Huis te Linschoten", Bulletin Koninklijke Nederlandse Oudheidkundige Bond 98 (1999) 141-151. 


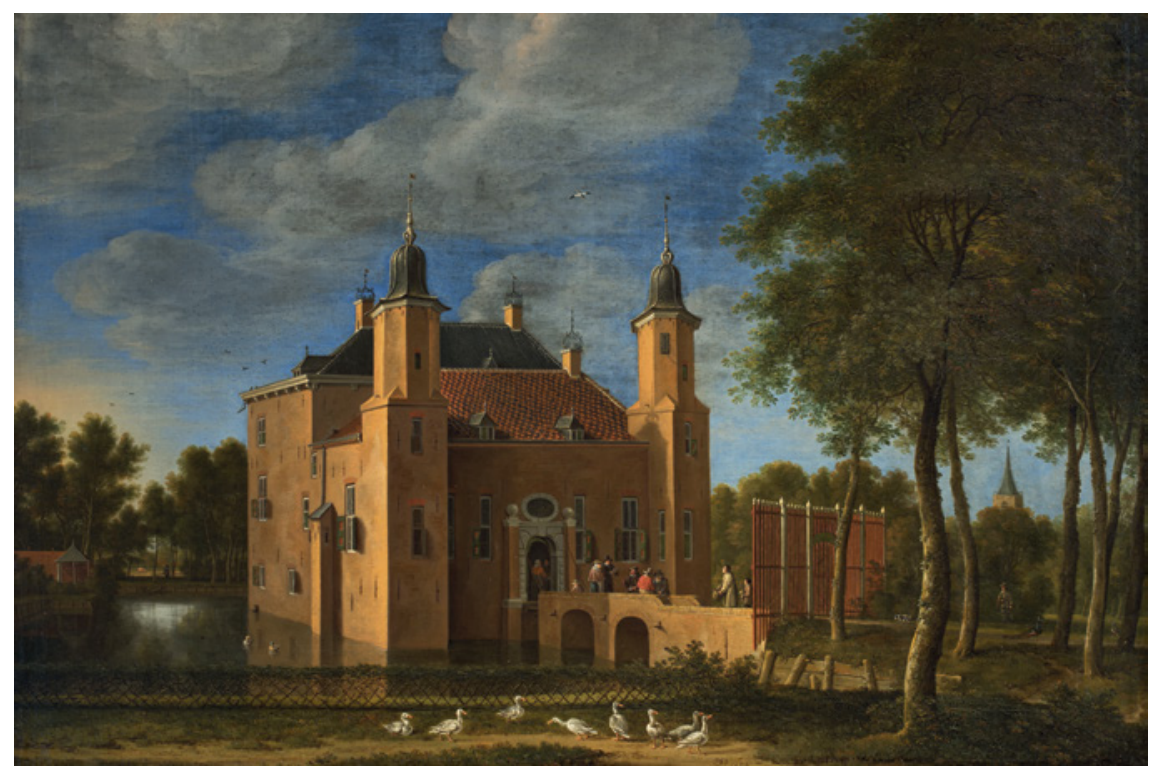

FIGURE 12.14 Herman Saftleven, Huis te Linschoten (1654). Oil on canvas, $88 \times 128 \mathrm{~cm}$ IMAGE (C) STICHTING LANDGOED LINSCHOTEN

\section{Polderburg, a Paper Castle}

Ilpenstein and Linschoten are fine examples of the prestige which an ancestral castle provided in the seventeenth century, even if it was of such recent construction that the mortar was figuratively still wet. Earlier on, we saw that certain rights could be derived from the possession of a ruined former nobleman's castle. In this regard, as in others, inventive suggestions could prove quite effective. A great dose of creativity, though, was needed to make it seem believable that some remains of foundations were traces of a 'forgotten' castle of which nobody had ever heard. The following example, from Rotterdam, demonstrates this. The industrialist, political regent, historian and amateur architect Jacob Lois (1620-1676) is best known as architect of the Schielandshuis in Rotterdam and as the author of a historical treatise on the local district, the Schieland: Oude ware beschryvinge van Schielant (1672). ${ }^{34}$ Among Lois' possessions around the mid-point of the seventeenth century was a small

34 Preserved as a manuscript in Stadsarchief [City Archive] Rotterdam, published in Unger J.H.W. - Bezemer W., De oudste kronieken en beschrijvingen van Rotterdam en Schieland (Rotterdam: 1895) vol. II 546-621. 
triangular polder between Schiedam and Delft, appropriately known as the 'Kleine Polder' ('small polder'). It was sandwiched between two larger polders, and was partly submerged in winter as a strategy to manage excess water. Lois presumably had higher things in mind for this patch of ground, located so usefully between Delft, Schiedam and Rotterdam, and the annual inundation was frustrating this commercial development. However, when he raised his dike along the stream, he became ensnared in an inevitable conflict with the dikewarden (dijkgraaf) and high commissioners (hoogheemraden) of Delfland, who bore responsibility for water management in the area. They commanded him to lower his dike again on pain of a stiff fine. In 1653 , Lois wrote a long refutation, seeking to prove that the property in question was a venerable old aristocratic estate which had long been kept drained. He asserted in olden days there had been a castle on the spot named 'Polderburg' (Polder Castle), founded in 1313 by the van Wassenaers, Holland's oldest noble family. Proof of this was provided by the remains of the old foundations which his workmen had found there, and by two remarkable stones, one bearing the old crest of the van Wassenaers, the other with an inscription in an antique script, reading 'POLDER BURCH / ANNO MCCCXIII'. In addition, Lois had a document to bolster his case: nothing less than a copy of a chronicle by one Willem van der Sluijs, dated 1509. This source declared that Kasteel Polderburg had been founded by Filips van Wassenaer in 1313 and destroyed in 1489. In the text, the author states that he obtained this information from a text supposedly written by the author's uncle, Simon Doedes van der Sluijs, in 1472. ${ }^{35}$

This story, with its associated inscribed stones and the chronicles of uncle and nephew van der Sluijs, was entirely a product of Jacob Lois' fecund imagination. ${ }^{36}$ He was eager to keep the Kleine Polder dry all year round in order to use it for any of several possible industrial uses. To make his wish a reality, he came up with an invented history which he then hoped to use to derive land rights. Lois had been very sly, in fact, in stitching together the noble history of his polderland: as an amateur historian, he was well familiar with the outline of Holland's past, and as a city father of Rotterdam, he even had access to the city archives. This way, he had been able to dig out a wealth of real events to attach to his own narrative. For instance, Simon Doede van der Sluijs was an historical figure of some significance: one of his roles was court physician to the Duke of Burgundy, and later on he was Canon of Utrecht Cathedral. His

35 Lois' copy was published in: Unger - Bezemer, De oudste kronieken en beschrijvingen vol. II $11-25$.

36 Scholte M.C.P., "Polderenburg", Rotterdams Jaarboekje (1978) 243-304, and idem, "Polderenburg II", Rotterdams Jaarboekje (1980) 236-255. 
nephew Willem, however, probably never existed; he was a creature of Lois' seventeenth-century mind. In his 'copy' of the so-called Chronicle of Simon van der Sluijs, Lois' own make-believe about Polderburg is carefully intermingled with historical facts known from other, reliable, sources, affording a degree of trustworthiness to the text at first glance. The van Wassenaer lords, for instance, although they had never owned the Kleine Polder, had indeed been lords of the ambacht of the local legal jurisdiction, the Ketelambacht, under which the land fell. This made the myth of an old van Wassenaer fortress plausible to contemporary historians. It could also quite possibly be true that mediaeval foundations had been found on the grounds, as Lois stated in his defence, but these could just as well have been remains of a lease barn or similar feudal construction. The inscribed stone, if indeed such ever existed, will have been a fake.

Whatever care and wistfulness Lois had lavished on his rebuttal, he was the loser of his case against the Delfland water commissioners. The Delfland secretary harboured doubts as to the veracity of the historical document 'Nor is it without major suspicion (if this chronicle is authentic at all) ...' but did not further enunciate them. ${ }^{37}$ Lois lost the case because Delfland was able to furnish proofs that the Kleine Polder had very much been used as a regular winter water storage facility in the past. However, the myth of Kasteel Polderburg had been born, and the genie could not be put back in the bottle. The connection with the old noble family of the van Wassenaers lent prestige to the possession of this parcel of ground. Lois sold the land for a handsome price in 1658 and the new owner disregarded its old name, Kleine Polder, in favour of a consistent use of the name Polderenburg, to keep the memory of the 'lost castle' alive. From that time on, that was the name given on maps. To insist further on his vindication, Lois also included the story of Polderburg Castle in his 1672 history of the Schieland, and a century later, this served as the basis of another historical description, this time of Rotterdam by the poet and draughtsman Jacob Kortebrant (1697-1777). ${ }^{38}$ The "vanished" castle evidently still so appealed to the imagination that in 1752, Kortebrant drew Polderburg as it supposedly looked before being ravished in 1489 [Fig. 12.15]: a product of his fantasy, of course, but it was at least based on the standard model of a modest fifteenth-century noble house, L-shaped with a stair tower in the inside corner,

37 Oud Archief [Old Archives] Delfland, inv. no. 3510/28, first document, page 2. (Scholte, "Polderburch II" 250).

38 Posthumously published as Beschryving der Stad Rotterdam, van haar eerste opkomst en aanleg af, en van de publyke gebouwen; gedeeltelyk getrokken uit nagelaate geschriften, van wylen den heer Jacob Kortebrand (Rotterdam: 1786-1787). 


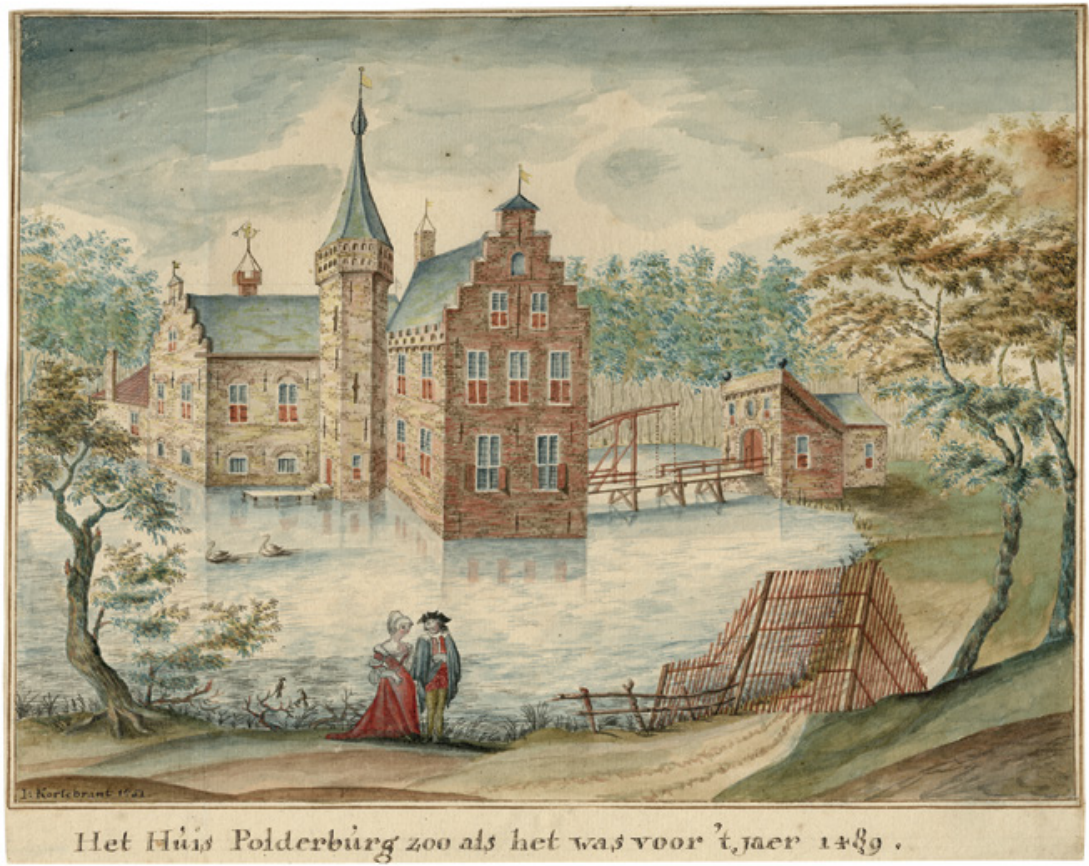

FIGURE 12.15 Jacob Kortebrant, Het Huis Polderburg zoals het was voor het jaar 1489. Drawing, $175^{2}$

IMAGE (C) GEMEENTEARCHIEF ROTTERDAM

in line with the summary description given it by pseudo-van der Sluijs (i.e. Lois): ' '.. with octagonal tower, a right proper building. ${ }^{39}$ Art is glad to oblige what people wish to see.

The Polderburg issue also demonstrates how persistent some of these stories proved to be. Made up as an argument of convenience in a dispute over water management, the land's noble backstory was increasingly cherished and embellished by subsequent generations. In the eighteenth century, the castle in the air acquired physical form, and from the nineteenth century onwards, the 'vanished castle' was even included in the first reasonably systematic gazetteers of Dutch antiquities. In this capacity, it was even mentioned on occasion in the twentieth century. The supposed chronicle of (pseudo-)Simon van der Sluijs of 1472 (in reality, Lois' work of 1653) was even taken at face value in 1895, by being included in an academic overview of materials on Rotterdam. Only

39 'met een achtcantige toren, sijnde een proper gebouw'. Unger - Bezemer, De oudste kronieken en beschrijvingen 609 . 
three centuries later, in 1978 , would this myth be deconstructed and found to be riddled with holes. ${ }^{40}$

In all the examples of real knightly fortresses, castles and imitation knightly fortresses discussed, we emphatically do not have to do with any kind of "chivalrous Romantic" style. In the seventeenth century, the deployment of archaic architectural forms harking back to mediaeval castles was not an expression of literary or romantic enamouredness of an idealised past. Rather, this architectural choice was motivated by political and social ambitions, the confirmation (or pretension) of deep-rootedness, and concern with the house's and family's rank and status. In an age in which historical precedence implied specific claims to power, building towers and moats was no fantasy game by the patron, nor an artistic whimsy by the architect; it was part of a strategy in which seeking connection to one's class of peers was just as vital as getting one up on undesirable arrivistes. Here, we have exclusively to do with the external display of chivalry. There was no trace of chivalrous elements in the internal architecture of the period; there, a family's ancient lineage was displayed through family portraiture, family trees and coats of arms, not with architectural features. In this regard, the castle architecture of the seventeenth century differs fundamentally from the Gothic revival of the nineteenth. Castles were no longer politically privileged by the time of the construction of houses such as De Schaffelaar outside Barneveld (1840) or Kasteel de Haar at Haarzuylen (1890). By that time, castle features had made way for Romantic allusions to mediaeval knightly honour, piety and/or virtue. To evoke that historical atmosphere as intensely as possible, Gothic forms were in the nineteenth century carried into the interior too, in the form of vaulting, wall timbers and even such minor details as lamps, furniture and door handles.

\section{Bibliography}

Bok M.J., "Laying claims to nobility in the Dutch Republic: epitaphs, true and false", in Eck X. van - Hecht P. (eds.), Ten essays for a friend:E. de Jongh 65, Simiolus 24, 2/3 (1996) 107-124.

$40 \quad$ Namely by M.C.P. Scholte (see note 36). 
Drie R. van, "Het begrip ridderhofstad in de 16de en 17de eeuw", in Olde Meierink B. et al. (eds.), Kastelen en ridderhofsteden in Utrecht 41-50.

Enenkel K.A.E. - Ottenheym K.A., Oudheid als ambitie. De zoektocht naar een passend verleden (Nijmegen: 2017).

Kuiper Y. - Olde Meierink B. (eds.), Buitenplaatsen in de Gouden Eeuw. De rijkdom van het buitenleven in de Republiek (Hilversum: 2015).

Olde Meierink B. - Baaren G. van - Bosch van Drakestein R.G. - et al. (eds.), Kastelen en ridderhofsteden in Utrecht (Utrecht: 1995).

Olde Meierink B., "Conflict tussen oud en nieuw. De zeventiende eeuw”, in Janssen H.L. Kylstra-Wielinga J.M.M. - Olde Meierink B. (eds.), 1000 Jaar kastelen in Nederland. Functie en vorm door de eeuwen heen (Utrecht: 1996) 142-170.

Olde Meierink B., "De grote toren: een adelssymbool?", Virtus. Bulletin van de werkgroep Adelsgeschiedenis 4 (1997) 1-10.

Ottenheym K.A., "Turm oder Portico? Die neuen Schlösser des Utrechter Adels im 17. Jahrhundert", in Hoppe S. - Müller M. - Nussbaum N. (eds.), Stil als Bedeutung in der nordalpinen Renaissance. Wiederentdeckung einer methodischen Nachbarschaft (Regensburg: 2008) 377-399.

Ottenheym K.A., “'The best and most competent at observing proportion'. Scamozzi's posthumous success in 17th-century Holland", in Barbieri F. - Avagnina M.E. Sanvito P. (eds.), Vincenzo Scamozzi. Teorico Europeo (Vicenza: 2016) 194-231. 